\title{
Article \\ An Analysis of the Microstructure of the Melting Layer of a Precipitating Stratiform Cloud at the Dissipation Stage
}

\author{
Lei Wei ${ }^{1}$, Hengchi Lei ${ }^{2,3, *}$, Wenhao Hu ${ }^{2,3}$, Minsong Huang ${ }^{2}$, Rong Zhang ${ }^{4}$, Xiaoqing Zhang ${ }^{2}$, Tuanjie Hou ${ }^{2, *}$ \\ and Yuhuan $L \ddot{u}^{5, *}$ \\ 1 Beijing Weather Modification Center, Beijing 100089, China; weilei@mail.iap.ac.cn \\ 2 Institute of Atmospheric Physics, Chinese Academy of Sciences, Beijing 100029, China; \\ huwenhao@mail.iap.ac.cn (W.H.); mission@mail.iap.ac.cn (M.H.); zhangxq@mail.iap.ac.cn (X.Z.) \\ 3 College of Earth and Planetary Sciences, University of Chinese Academy of Sciences, Beijing 100049, China \\ 4 China Meteorological Administration (CMA) Weather Modification Centre (WMC), Beijing 100081, China; \\ zhangrong@cma.gov.cn \\ 5 Wuqing Meteorological Observatory of Tianjin, Tianjin 301700, China \\ * Correspondence: leihc@mail.iap.ac.cn (H.L.); houtj@mail.iap.ac.cn (T.H.); lvyh@tjwq.gov.cn (Y.L.)
}

check for updates

Citation: Wei, L.; Lei, H.; Hu, W.; Huang, M.; Zhang, R.; Zhang, X.; Hou, T.; Lü, Y. An Analysis of the Microstructure of the Melting Layer of a Precipitating Stratiform Cloud at the Dissipation Stage. Atmosphere 2022, 13, 284. https://doi.org/ $10.3390 /$ atmos 13020284

Academic Editor: Bryan C. Weare

Received: 27 December 2021

Accepted: 4 February 2022

Published: 8 February 2022

Publisher's Note: MDPI stays neutral with regard to jurisdictional claims in published maps and institutional affiliations.

Copyright: (C) 2022 by the authors. Licensee MDPI, Basel, Switzerland. This article is an open access article distributed under the terms and conditions of the Creative Commons Attribution (CC BY) license (https:// creativecommons.org/licenses/by/ $4.0 /)$.

\begin{abstract}
In this study, we investigated the macro- and microstructures of layered precipitation clouds in spring in Jilin Province, China. The premise of the campaign was to observe cloud particles in the melting layer (ML). The weather was developed under the influence of the Mongolia cyclone, which brought a large range of precipitation to the northeast. Combining the Droplet Measurement Technology (DMT) and Particle Measuring Systems (PMS) data, small particles accounted for the majority of all particles at each level above and below the ML. In our observations, both ice crystals $(50-300 \mu \mathrm{m})$ and snowflakes $(>300 \mu \mathrm{m})$ had two peaks between -5 and $-2{ }^{\circ} \mathrm{C}$. The high concentration of ice crystals at a temperature of $-2.65^{\circ} \mathrm{C}(4865 \mathrm{~m})$ attained a maximum value of $287 \mathrm{~L}^{-1}$ and snowflakes with $47 \mathrm{~L}^{-1}$, which was similar to the previous studies. The Hallett-Mossop ice multiplication process operated most effectively at the temperature of $-5{ }^{\circ} \mathrm{C}$ in this study. Even at the cloud dissipation stage, new droplets were still generated between -5 and $-6{ }^{\circ} \mathrm{C}$, providing abundant liquid water content (LWC) for the upper cloud. Although irregulars were observed, needles and spheres dominated in the observed cloud region of low LWC $\left(<0.1 \mathrm{~g} \mathrm{~m}^{-3}\right)$ at temperatures of -6 to $-3{ }^{\circ} \mathrm{C}$. These cloud conditions fit into the Hallett-Mossop criteria.
\end{abstract}

Keywords: stratiform cloud; melting layer; particle size distribution (PSD); microphysical

\section{Introduction}

Regarding precipitation clouds, the vertical cloud structure reflects the dynamic and thermal structural characteristics and microphysical characteristics of precipitation cloud clusters [1-4]. Many observations and analyses have revealed that the structure of stratiform clouds and the precipitation process are complicated, related not only to the concentration of ice crystals in clouds, cloud thickness, and supercooled water content, but also to the characteristics of the warm layer and the microphysical and dynamic processes in clouds [5-9]. In situ aircraft measurements of these clouds enable us to better understand cloud microphysics [10-15]. Ice crystal habits in the melting layer (ML), where snow melts to rain, is central to understanding the formation and growth processes of particles in the clouds.

To better understand the characteristics of stratiform cloud precipitation, we must consider the detailed microphysical processes and properties of the melting layer (ML) such as the continuous growth of aggregates via the agglomeration of small particles, the fragmentation of these aggregates, and the effect on particle melting, which have not been resolved [16]. Melting is a very important process in cooling air, which generates a downdraft. Changing the density and temperature of ice particles affects the falling speed, 
particle size distribution (PSD), and mass distribution of these particles. Most current research on the upper and lower regions of the ML has relied on ground-based cloud radar measurements [17-19]. Above the ML, in situ images and triple-frequency radar signatures both indicated the presence of moderately rimed aggregates [18]. Heymsfield et al. suggested that the radar-bright band was due to these relatively few, very large aggregates that survive to warmer temperatures $[19,20]$. Willis and Heymsfield concluded that most of the ice mass melted, and thus most of the cooling of air occurred in a thin layer above the location of the radar-bright band [20].

In previous studies, the ice crystals in the ML were usually assumed to be ice crystal particles of a specific shape. The melting process of particles was capable of modulating the thermal structure of the ML through the exchange of latent heat with the environment [21], and as a result, may change the precipitation dynamics [9,22]. Carlin and Ryzhkov [21] found that, in addition to riming, concurrent changes in aggregation and precipitation intensity and the associated cooling may plausibly cause the observed sagging bright band signatures. ML properties were modified by the ambient environment, and microphysical processes taking place in the ML [23]. Such melting effects ultimately lead to a decrease in particle size, the consequent decrease in particle concentration, and a signal reduction below the radar-bright band [24]. Heymsfield et al. [25] found that if the relative humidity was too low, the particles will sublimate completely as they fall into the melting layer, but snow pellets survive to even warmer temperatures. The growth process of particles could be inferred from the melting characteristics of ice particles [26,27].

Previous studies have shown that the ice crystals' habits were dependent on the cloud temperature [28-30]. Melting proceeded from the smallest to the largest particles, beginning between +0.5 and $+1{ }^{\circ} \mathrm{C}$ and ending at about $+2{ }^{\circ} \mathrm{C}$ [16]. Hou et al. [12] found that ice particle habits were characterized by dendrites at $-1{ }^{\circ} \mathrm{C}$, needles at $-3{ }^{\circ} \mathrm{C}$, and again, dendrites and irregulars between -6 and $-9^{\circ} \mathrm{C}$ with few spheres coexisting. A mixture of several ice crystal' habits was identified at temperatures between 0 and $-16^{\circ} \mathrm{C}$ in all of the clouds studied [15]. The rimed ice particles and needles coexisted at temperatures between -3 and $-5{ }^{\circ} \mathrm{C}$ in the embedded convective region [13]. Ice splinters produced during riming could account for the relatively high concentrations of ice particles in clouds that encompass temperatures between -2.5 and $-8{ }^{\circ} \mathrm{C}$ [9]. The Hallett-Mossop process and fragmentation of freezing drops cannot fully explain the observed high ice concentration in shallow stratiform clouds without significant riming occurring [31].

In this study, we investigated the macro- and microstructures of layered precipitation clouds in spring in Jilin Province, China. With the use of comprehensive detection data of the stratiform cloud system on 29 June 2012, the characteristics of cloud particles measured during aircraft detection, the corresponding condensation mechanism and the microphysical process and properties of the ML were analyzed in detail. The rest of this paper is organized as follows. In Section 2, the case data are described and presented. Details on the flight experimental design and setup are provided in Section 3. In Section 4, the in situ aircraft measurements are described, the case results are examined, and a comparison of these results to the measured data is presented. Finally, a summary and our conclusions are presented in Section 5.

\section{Data Description}

Two Y-12 aircrafts, provided by the Baicheng and Tongliao Weather Modification Offices, individually equipped with in situ cloud microphysical probes manufactured by Particle Measuring Systems (PMS) and Droplet Measurement Technology (DMT). The cooperative exploration flight experiment included vertical and horizontal measurements at different precipitation stages and levels in the target area. The flight features including the beginning and end times and the airborne detection instruments are listed in Table 1. The project consisted of two instrumented aircraft making two short flights through the cloud. 
Table 1. Flight features including aircraft, beginning and end times, and main instruments.

\begin{tabular}{clcc}
\hline Date & Aircraft & Time (CST-hhmm) & Main Instruments \\
\hline 29 June 2012 & Tongliao & First flights: 0607-0738 & CAS, PIP, CIP, and CCN \\
29 June 2012 & Baicheng & Fecond flights: 0854-1025 & First flights: 0557-0751 \\
& second flights: 0856-1014 & FSP-100, 2D-P, and 2D-C \\
\hline
\end{tabular}

CST: China Standard Time.

The Tongliao aircraft was instrumented with a cloud and aerosol spectrometer (CAS) with a size range from 0.61 to $50 \mu \mathrm{m}$, a precipitation imaging probe (PIP) with a size range from 100 to $6200 \mu \mathrm{m}$, and a 2D cloud imaging probe (CIP) with a size range from 25 to $1550 \mu \mathrm{m}$. The Baicheng aircraft was equipped with a forward scattering spectrometer probe (FSSP-100) with a size range from 0.5 to $47 \mu \mathrm{m}$, an OAP-2D-P (2D-P) with a size range from 100 to $6400 \mu \mathrm{m}$, and an OAP-2D-C (2D-C) with a size range from 25 to $800 \mu \mathrm{m}$. The Tongliao aircraft was equipped with a condensation nuclei counter $(\mathrm{CCN})$ with a size range from 0.5 to $10 \mu \mathrm{m}$. In addition to the above probes, the aircraft were equipped with an Aircraft Integrated Meteorological Measurement System (AIMMS-20, Aventech Research Inc., Ontario, Canada) and a liquid water content-100 (LWC-100) instrument.

\section{Flight Experimental Design}

The two aircraft took off from Baicheng Airport to observe the same stratiform cloud precipitation system. A very rigorous experimental design was established to analyze the precipitation process of stratiform clouds. The experiment mainly focused on the vertical distribution of the precipitation microstructure. To ensure representative observation results, sixteen horizontal flight trajectories associated with precipitating clouds over Baicheng were selected in the study.

The observation area of this experiment was mainly in Baicheng. Baicheng is inland, which located at the northernmost end of Jilin Province, connected to Inner Mongolia and Heilongjiang. It belongs to the semi-arid monsoon climate area of the middle temperate zone. On 29 June 2012, the two aircraft carried out two detection campaigns of the cloud system including thirty-seven horizontal flight legs (Figures 1 and 2). All flight legs targeting the same cloud case were executed in the morning, except that they occurred at different horizontal levels. This study selected sixteen horizontal flight legs above $3.0 \mathrm{~km}$ and below $6.0 \mathrm{~km}$ during aircraft ascent and mainly studied the PSDs near the height of the ML. The corresponding horizontal flight information is listed in Table 2.

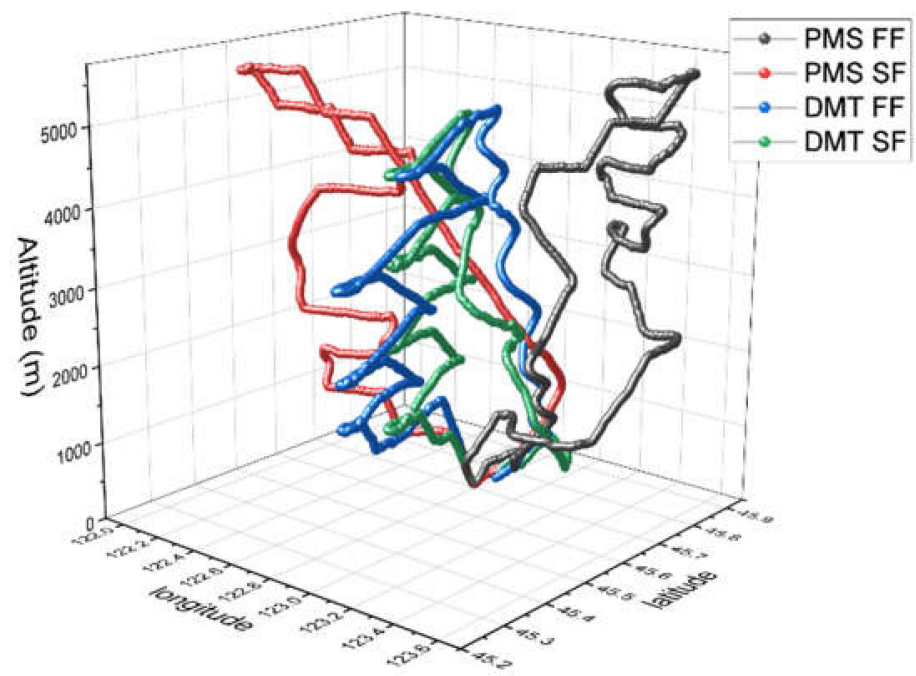

Figure 1. Three-dimensional trajectory diagram of the two aircraft (black: PMS aircraft first flights (PMS FF), red: PMS aircraft second flights (PMS SF), blue: DMT aircraft first flights (DMT FF), green: DMT aircraft second flights (DMT SF)). 

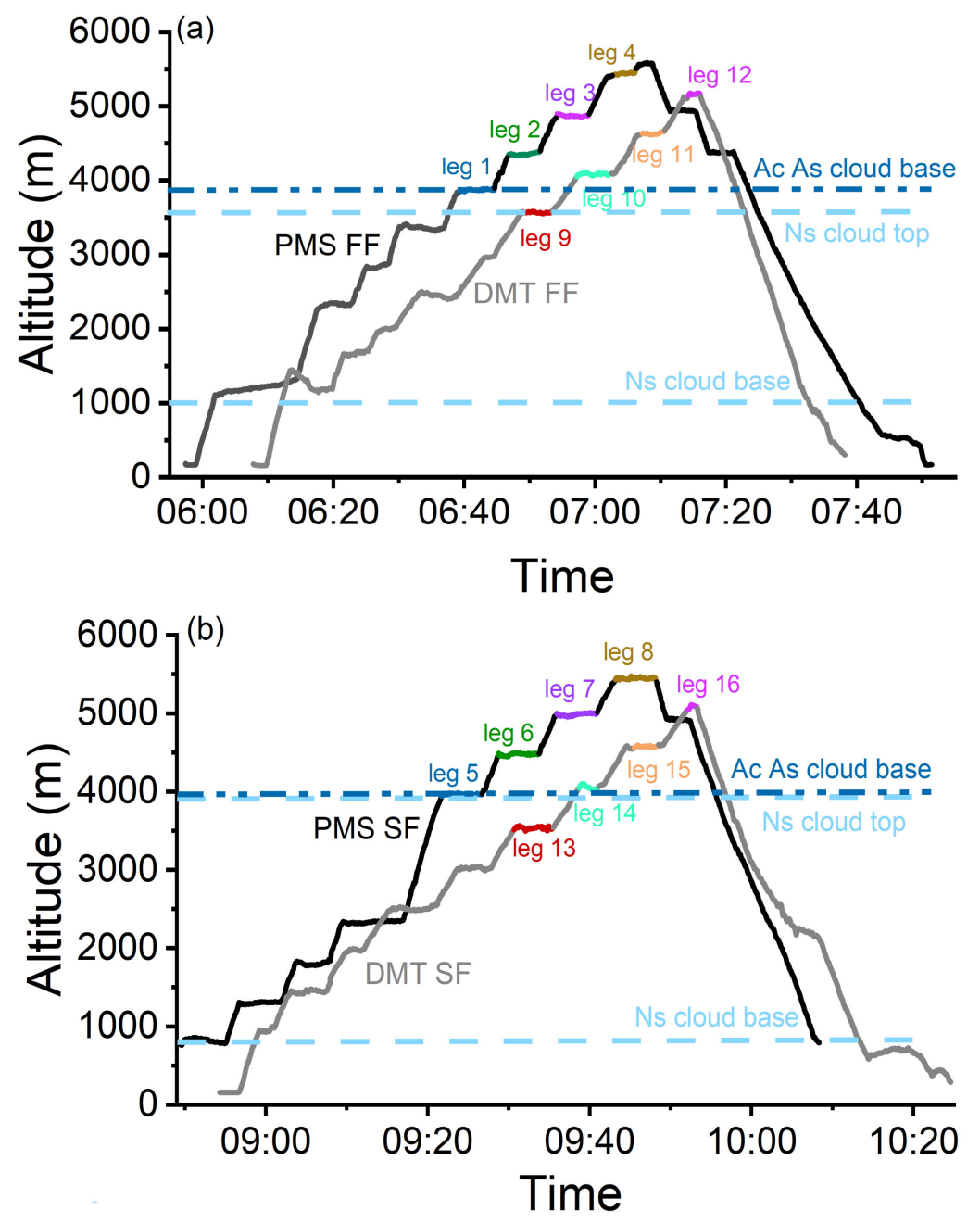

Figure 2. Detection flight trajectories: Time-Altitude diagram: (a) black: PMS FF, gray: DMT FF (b) black: PMS SF, gray: DMT SF.

Table 2. Horizontal flight leg features including aircraft, beginning and end times, altitude, and cloud temperature.

\begin{tabular}{ccccc}
\hline No. & Aircraft & Time $(\mathbf{C S T}-\mathbf{h h m m})$ & Altitude $\mathbf{( k m )}$ & Temperature $\left({ }^{\circ} \mathbf{C}\right)$ \\
\hline leg 1 & Baicheng & $0639-0644$ & 3.85 & From 0.7 to 1.7 \\
leg 2 & Baicheng & $0646-0651$ & 4.35 & From -1.3 to 0.3 \\
leg 3 & Baicheng & $0654-0659$ & 4.85 & From -3.8 to -1.6 \\
leg 4 & Baicheng & $0702-0706$ & 5.45 & From -5.25 to -4.35 \\
leg 5 & Baicheng & $0921-0926$ & 3.95 & From 0.95 to 2.1 \\
leg 6 & Baicheng & $0928-0933$ & 4.46 & From -2.55 to -0.55 \\
leg 7 & Baicheng & $0936-0940$ & 5.0 & From -5.0 to -3.4 \\
leg 8 & Baicheng & $0943-0947$ & 5.42 & From -6.15 to -5.25 \\
leg 9 & Tongliao & $0649-0653$ & 3.58 & From 4.16 to 4.33 \\
leg 10 & Tongliao & $0657-0702$ & 4.09 & From 1.85 to 2.62 \\
leg 11 & Tongliao & $0706-0710$ & 4.65 & From 0.45 to 1.64 \\
leg 12 & Tongliao & $0714-0716$ & 5.16 & From -2.65 to -2.08 \\
leg 13 & Tongliao & $0930-0935$ & 3.52 & From 4.8 to 5.9 \\
leg 14 & Tongliao & $0938-0940$ & 4.05 & From 2.94 to 3.8 \\
leg 15 & Tongliao & $0945-0948$ & 4.59 & From 0.33 to 0.86 \\
leg 16 & Tongliao & $0951-0952$ & 5.08 & From -2.4 to -0.68 \\
\hline
\end{tabular}

Note: Temperature-hundredths of Celsius degree; altitude—units of meters. 
The stratiform cloud precipitation process was developed under the influence of a Mongolia cyclone, which caused large-scale precipitation in northeast China. At the mature precipitation stage, there was a clear bright band, and cloud development occurred relatively vigorously. Altostratus (As), altocumulus (Ac), and nimbostratus (Ns) were the main cloud systems, accompanied by low-level fractonimbus clouds. The Ns base occurred at approximately $1.0 \mathrm{~km}$; the top was not higher than $4.0 \mathrm{~km}$ (Figure 2). There were fractonimbus clouds below the Ns cloud system, which were thicker during the development of the cloud system. The bright band of the radar echo was observed at 06:22, after which the cloud system gradually weakened. During the aircraft flights, the main cloud system had already reached the late stage of precipitation, and the bright band of the radar echo gradually disappeared.

\section{In Situ Aircraft Measurements}

\subsection{Vertical Variation in the Particle Habits}

According to the first flight records, precipitation reached the ground when the Tongliao aircraft took off at 06:05. The plane entered the cloud system, and the height of the cloud base occurred at approximately $1000 \mathrm{~m}$, and the Ns cloud top occurred at approximately $3583 \mathrm{~m}$. The aircraft entered the upper layer of the cloud system at $3900 \mathrm{~m}$, in which Ac and As clouds existed. The CAS and FSSP probe detected aerosols and cloud droplets below the $0{ }^{\circ} \mathrm{C}$ layer, while above the $0{ }^{\circ} \mathrm{C}$ layer, ice crystals and droplets coexisted.

Figure 3 shows the vertical distribution of cloud droplets measured by the CAS and FSSP. The particle concentration, diameter, and LWC measured by the CAS were less than $1 \mathrm{~cm}^{-3}, 10.88 \mu \mathrm{m}$, and $0.0018 \mathrm{~g} \mathrm{~m}^{-3}$ separately from temperatures from -3 to $-2{ }^{\circ} \mathrm{C}$. There was a LWC value of $0 \mathrm{~g} \mathrm{~m}^{-3}$ between -2 and $1.4^{\circ} \mathrm{C}$, indicating that the aircraft was outside the cloud. However, the maximum cloud droplet concentration measured by the FSSP in the layer with a temperature of $-0.55^{\circ} \mathrm{C}$ was $65.5 \mathrm{~cm}^{-3}$. In the $0{ }^{\circ} \mathrm{C}$ layer, the maximum average cloud droplet diameter reached $13.5 \mu \mathrm{m}$. The maximum value of LWC in the clouds was lower than $0.028 \mathrm{~g} \mathrm{~m}^{-3}$. The FSSP and CAS probes detected that the cloud particle concentration revealed a multipeak distribution. Sampling strategy and limitations exist in aircraft observation and it is difficult to assess how the properties of a cloud change in the vertical direction from data averaged for different levels [32,33]. The concentration number, average diameter, and LWC of the same cloud system varied greatly at different locations, and the difference was similar to that of two precipitating stratiform cloud systems in Hou et al. [12]. The cloud detected by DMT had a two-layer structure with a cloud-free area in the middle, while the cloud systems detected by PMS were continuous.
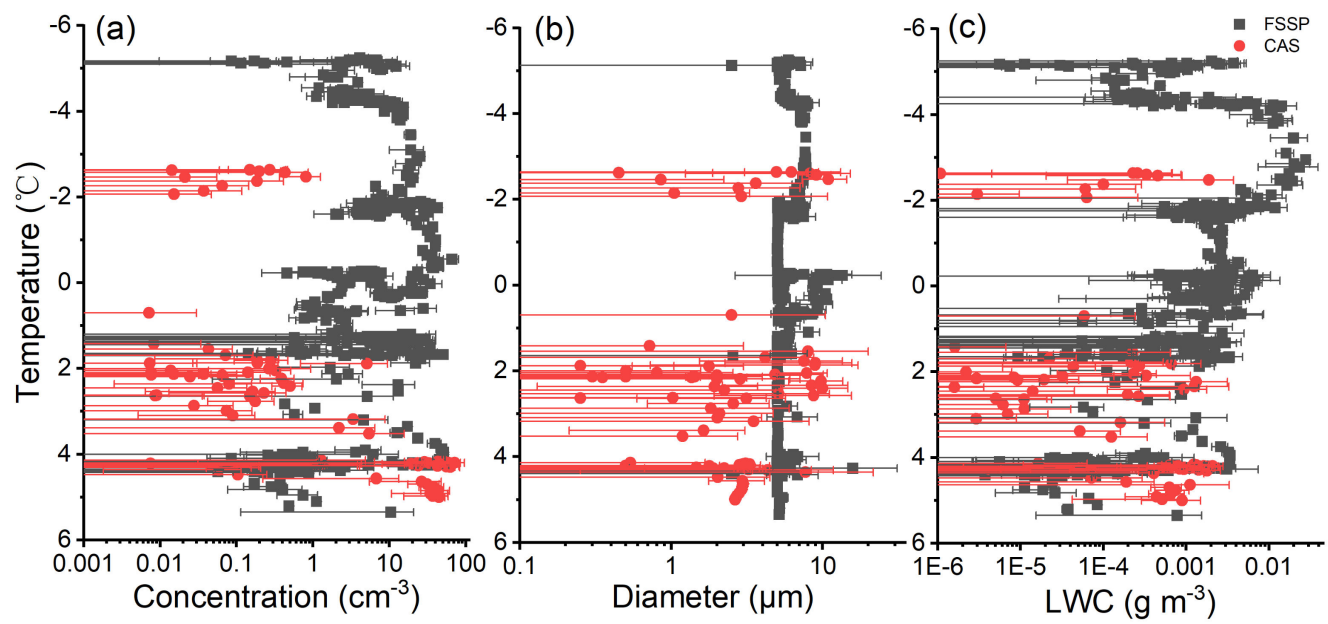

Figure 3. Based on the DMT-CAS data (red circles: 2-45 $\mu \mathrm{m}$ ) FF and the PMS-FSSP data (black squares: $2-45 \mu \mathrm{m}$ ) FF, the variation in (a) the cloud droplet concentration, (b) average diameter, and (c) liquid water content (LWC). Standard deviations represent uncertainties in the probe detection. 
During the FSSP SF (Figure 4), the cloud droplet concentration distribution was larger than that during the first flight from the -6 to $-5{ }^{\circ} \mathrm{C}$ layer and -2 to $-3{ }^{\circ} \mathrm{C}$ layer (as shown in Figure 4a). The diameter seems to have discrete intervals for FSSP, which is not physical and comes from instrument limitations or program bias (as shown in Figures $3 \mathrm{~b}$ and $4 \mathrm{~b}$ ). In the -6 to $-4.5^{\circ} \mathrm{C}$ layers, the LWC was high with a maximum value of $0.025 \mathrm{~g} \mathrm{~m}^{-3}$. Even at the cloud dissipation stage, new droplets were still generated between -5 and $-6{ }^{\circ} \mathrm{C}$, providing abundant LWC for the upper cloud. This was consistent with Hou et al. [13], in which the peak LWC was generally less than $0.1 \mathrm{~g} \mathrm{~m}^{-3}$ was observed from -3 to $-6{ }^{\circ} \mathrm{C}$ cell in the stratiform regions. However, LWC was much smaller in our case.
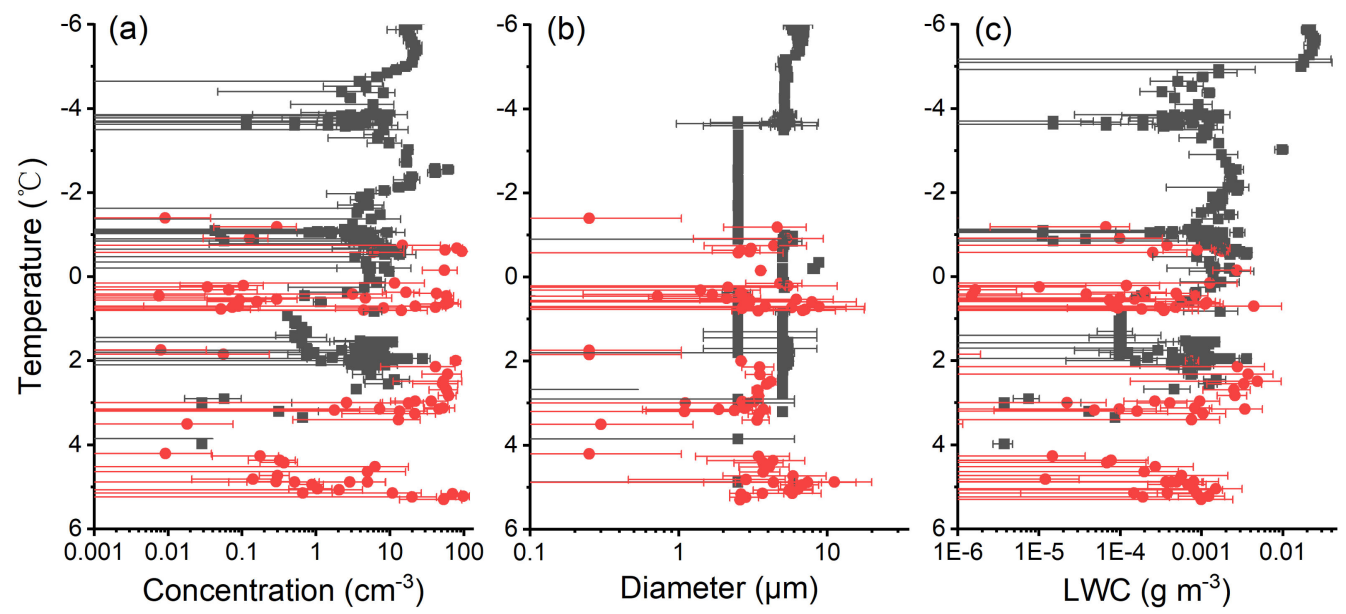

Figure 4. The same as in Figure 3, the SF variation in (a) the cloud droplet concentration, (b) average diameter, and (c) LWC.

Measurements of concentrations in many cases exhibited large uncertainties (Figures 3 and 4). In comparison, CAS was more discrete than FSSP, so the FSSP data were more reliable. The profiles of the total concentration, average diameter, and LWC as a function of temperature in the ML were summarized. Within the critical temperature range from 0 to $+1^{\circ} \mathrm{C}$, the uncertainty in the observations was larger than any trend in this small temperature range. For ice particles, there was no obvious increase in total concentration and average diameter in the ML with the FSSP probe. Ice particles melted into raindrops as the temperature increased. Moreover, the fall speed of the raindrops was higher than that of the ice particles. Consequently, the total concentration of ice particles decreased. However, the results in ML by the CAS probe were quite different. In contrast to the results by the FSSP probe, total concentration, average diameter, and LWC measured by the CAS probe were all increased in ML. The falling and melting of the large upper ice and snow crystal particles is one plausible explanation.

\subsection{Particle Size Distribution and Spectral Parameters}

Figure 5 shows the average PSD at different altitudes, as listed in Table 2. The concentration data from the CAS, FSSP, 2D-C, and CIP were averaged over the same altitude to reduce spurious variability. Regarding particles larger than $2 \mu \mathrm{m}$, the concentration was plotted on logarithmic axes, with the size plotted on linear axes. The highest cloud droplet concentration was observed for the $2-\mu \mathrm{m}$ cloud droplets at all flight altitudes. There was a small peak value from approximately 5-7 $\mu \mathrm{m}$ measured by the CAS. The diameters of the cloud droplets mostly varied between $2 \mu \mathrm{m}$ and $10 \mu \mathrm{m}$, and the concentration of cloud droplets with a particle diameter larger than $10 \mu \mathrm{m}$ was less than $0.3 \mathrm{~cm}^{-3} \mu \mathrm{m}^{-1}$.

The concentration of cloud droplets measured with the FSSP SF in each bin $(>10 \mu \mathrm{m})$ was lower than that of FSSP FF, and the shape of the PSD became narrower at the latter stage. This could be related to the descent of particles through the As and Ac clouds, leading to a rapid decrease in cloud droplets and an increase in the concentration of cloud 
droplets in the Ns cloud system. The broadening of the particle spectrum from $3.5 \mathrm{~km}$ to $4.59 \mathrm{~km}$ measured with the CAS SF also showed that phenomenon.
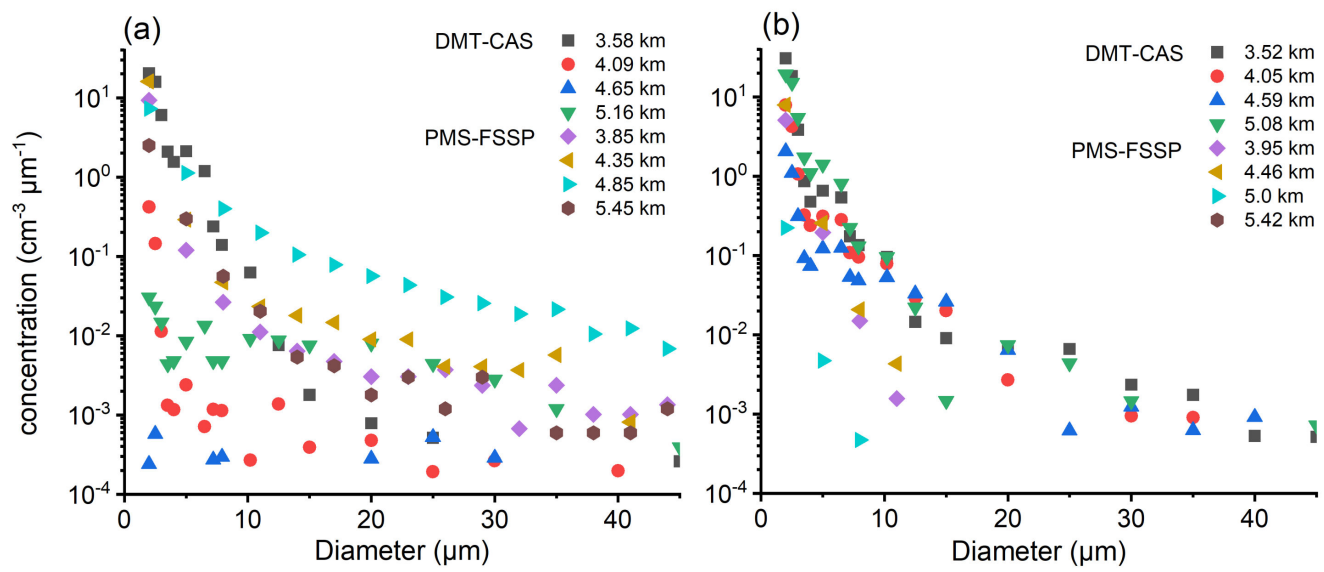

Figure 5. PSD (2-45 $\mu \mathrm{m})$ detected by FF: (a) PMS-FSSP $(3.85,4.35,4.85,5.45 \mathrm{~km})$, DMT-CAS (3.58, 4.09, 4.65, 5.16 km), SF: (b) PMS-FSSP (3.95, 4.46, 5.0, $5.42 \mathrm{~km})$, DMT-CAS (3.52, 4.05, 4.59, $5.08 \mathrm{~km})$.

During the CIP SF (Figure 6b), the cloud particles increased at each horizontal flight leg (except for $5.08 \mathrm{~km}$ ). The maximum diameter of cloud particles measured by the FSSP SF was smaller than $330 \mu \mathrm{m}$ at $3.95 \mathrm{~km}$, and the peak value of the cloud particle concentration in the Ns cloud top could reach $20 \mathrm{~L}^{-1} \mu \mathrm{m}^{-1}$. The concentration of ice and snow crystals that melted and fell into Ns cloud increased rapidly. The concentration of ice and snow crystal particles in the cloud near $5.4 \mathrm{~km}$ was larger than that in the FF, and a large number of ice and snow crystal particles were generated.
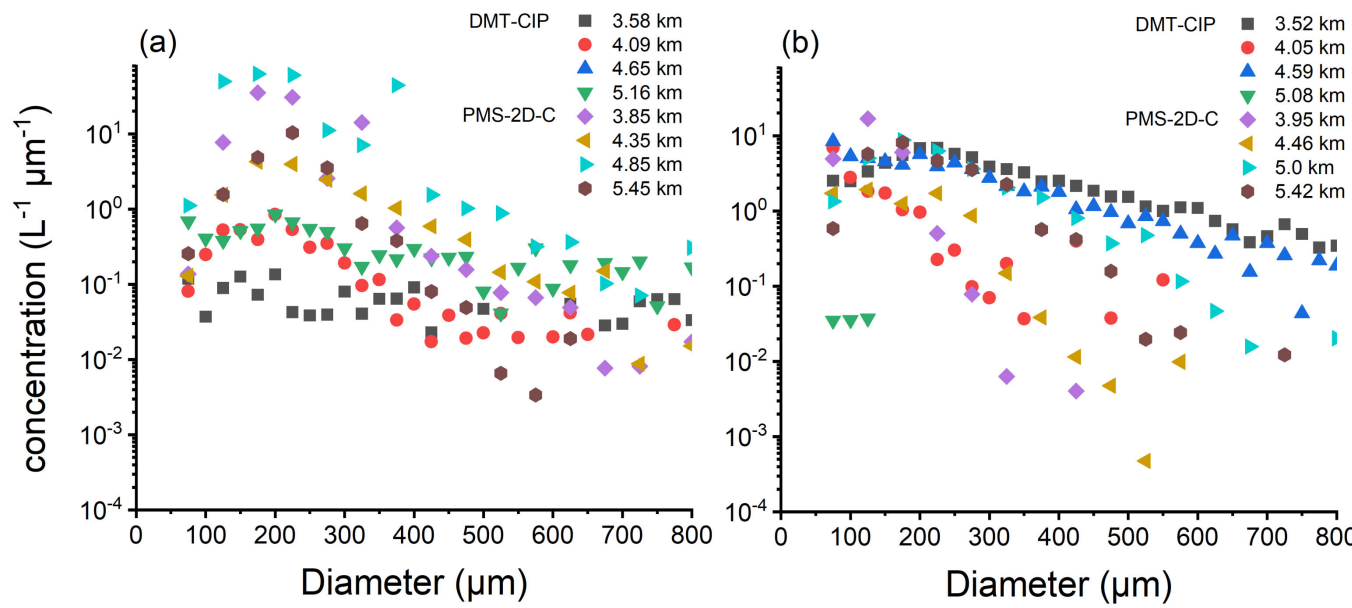

Figure 6. PSD $(75-800 \mu \mathrm{m})$ detected by FF: (a) PMS-2D-C $(3.85,4.35,4.85,5.45 \mathrm{~km})$, DMT-CIP $(3.58$, $4.09,4.65,5.16$ km), SF: (b) PMS-2D-C (3.95, 4.46, 5.0, 5.42 km), DMT-CIP $(3.52,4.05,4.59,5.08$ km).

The ice and snow crystal particles between -3 to $0{ }^{\circ} \mathrm{C}$ decreased due to melting and precipitation. At $5.16 \mathrm{~km}$, the concentration of ice crystal and snow crystal was less than $1 \mathrm{~L}^{-1}$ (as shown in Figures 6a and 7a,b), and both were less than $0.1 \mathrm{~L}^{-1}$ at $5.08 \mathrm{~km}$ (as shown in Figures $6 \mathrm{~b}$ and $7 \mathrm{c}, \mathrm{d})$.

The formation and growth mechanisms of ice particles could greatly affect initiation and duration of precipitation. Regarding the cloud particles detected by the 2D-C and CIP probe, the particles between 50 and $300 \mu \mathrm{m}$ in size above the $0{ }^{\circ} \mathrm{C}$ layer were regarded as ice crystals, and those with a diameter larger than $300 \mu \mathrm{m}$ were regarded as snowflakes, as in previous studies $[12,34,35]$. The formation and growth of ice and snow crystals in the cold layer play a notable role in precipitation. 

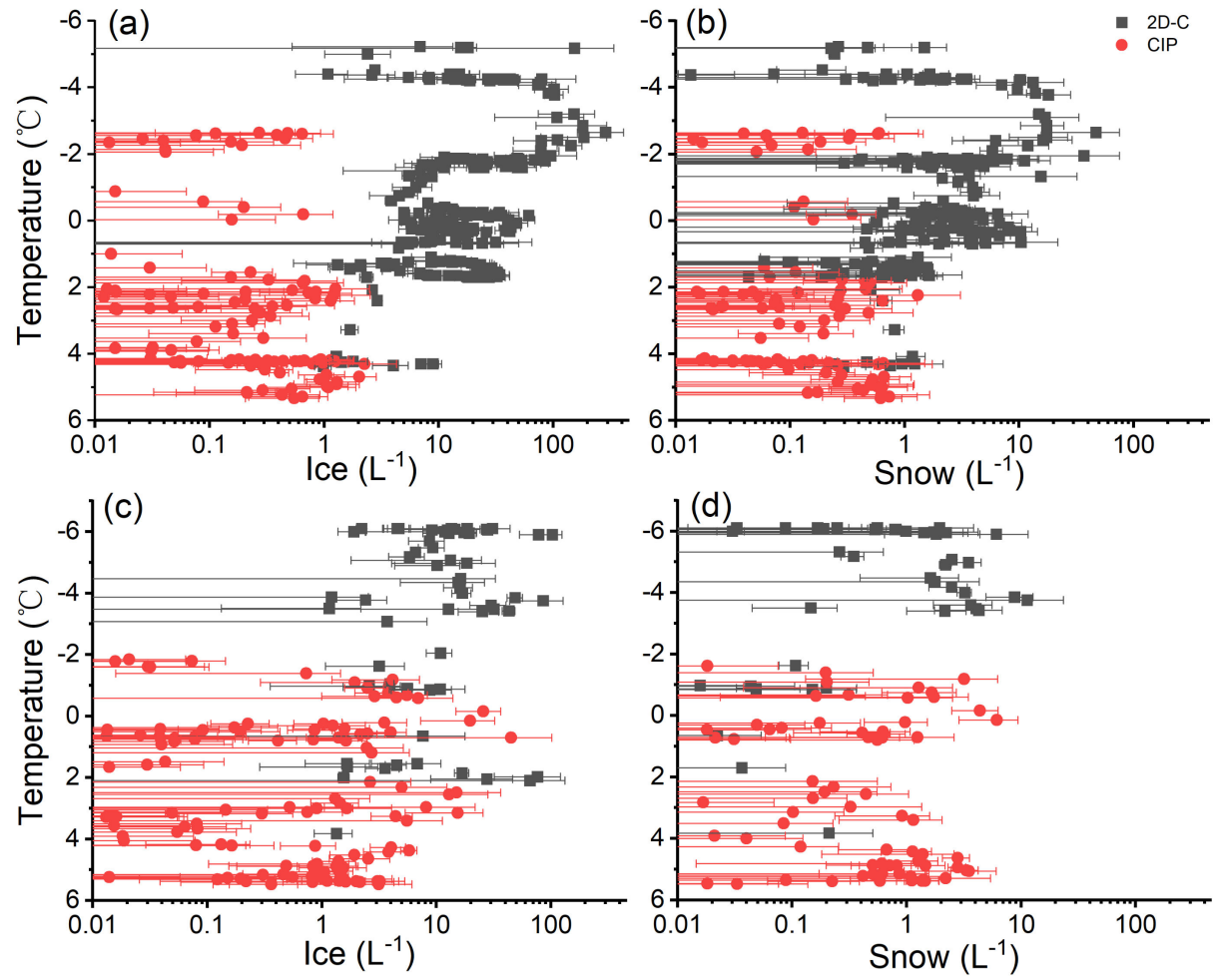

Figure 7. Variation and standard deviations with the height detected by the PMS-2D-C and the DMT-CIP probe FF: (a) ice crystal concentration and (b) snow crystal concentration. The SF: (c) ice crystal concentration and (d) snow crystal concentration (black squares: 2D-C; red circles: CIP). Standard deviations represent uncertainties in the probe detection.

Rangno and Hobbs [9] and Yang et al. [14] found that ice concentration was between 10 and $100 \mathrm{~L}^{-1}$ in the stratiform cloud, while in the cumulus cloud, the maximum ice concentration could be more than several hundred per liter [36,37]. In this study, ice crystals were generated faster during the first detection, which could be related to the multiplication process. Above $0{ }^{\circ} \mathrm{C}$, the ice crystal concentrations first increased and then decreased with decreasing temperature and then increased in the $-5^{\circ} \mathrm{C}$ layer. The concentration of ice crystals at a temperature of $-2.65{ }^{\circ} \mathrm{C}(4865 \mathrm{~m})$ attained a maximum value of $287 \mathrm{~L}^{-1}$ and snowflakes of $47 \mathrm{~L}^{-1}$. This was similar to previous studies, where ice crystal concentration was $348 \mathrm{~L}^{-1}$ and snowflakes was $73.5 \mathrm{~L}^{-1}$ [12]. The distribution of the concentration of snow crystals was similar to that of the concentration of ice crystals, as detected by the aircraft. However, high concentrations of large particles were found in the 2D-C SF, ice crystal concentration was up to $103 \mathrm{~L}^{-1}$, and snowflakes with $11.3 \mathrm{~L}^{-1}$ at temperatures from -3.5 to $-6{ }^{\circ} \mathrm{C}$.

Due to the low altitude of DMT aircraft, only particle spectrum information below $-2{ }^{\circ} \mathrm{C}$ can be obtained (as shown in Figure 7). When the temperature was higher than $0{ }^{\circ} \mathrm{C}$, the particles consisted of melting ice, snow crystal particles, cloud drops, and raindrops. The particle number concentration of ice crystal and snowflakes at about $-2{ }^{\circ} \mathrm{C}$ was less than $1 \mathrm{~L}^{-1}$, respectively. The value by $\mathrm{CIP}$ around $-2{ }^{\circ} \mathrm{C}$ was much smaller than that detected by 2D-C probe; comparison below $-3{ }^{\circ} \mathrm{C}$ was not feasible due to a lack of data. There was large uncertainty in the concentration of ice and snow crystals.

Considering the previous experimental results $[13,22]$, we concluded that high concentrations of cloud droplets and large ice particles provided a favorable environment for ice multiplication in our case, even at the cloud dissipation stage. Although observations were conducted during the ML of the stratiform clouds in this case, particle properties from lower temperature to high temperature stages could reveal the weakening of precipitation [12]. Both ice crystals and snowflakes had two peaks between -5 and $-2{ }^{\circ} \mathrm{C}$. For the 
mixed-phase layer, ice and snowflake particle concentrations increased with decreasing height until 0.5-1.0 km above the $0{ }^{\circ} \mathrm{C}$ layer [37].

\subsection{Characteristics of the Melting Layer ( $M L)$}

In fact, by the time of the aircraft observations, the radar-bright bands had disappeared. Figure 8 shows the particle shape and average diameter in the ML. There were irregular particles at a height of $4079 \mathrm{~m}$ (temperature: $0.2{ }^{\circ} \mathrm{C}$ ), which could be formed by the descent of ice crystal particles above the $0^{\circ} \mathrm{C}$ layer (Figure 8a). Irregular particles were still detected at $3978 \mathrm{~m}$, which were partially melted. The aggregation of particles was observed at $3871 \mathrm{~m}$, and small spherical particles were detected at $3864 \mathrm{~m}$. The particles were almost completely melted, while the particles at $3605 \mathrm{~m}$ had melted into raindrops. Figure $8 \mathrm{~b}$ shows that the average particle diameter varied between 3650 and $4300 \mathrm{~m}$, mainly from 150-250 $\mu \mathrm{m}$. This indicated that the large ice crystal particles at this stage entered the ML above $0{ }^{\circ} \mathrm{C}$ and melted, accompanied by the ice crystal particle fragmentation process. The average particle diameter was small, which continued to decline. Then, the clouds and raindrops aggregated and grew, and the average particle diameter increased.

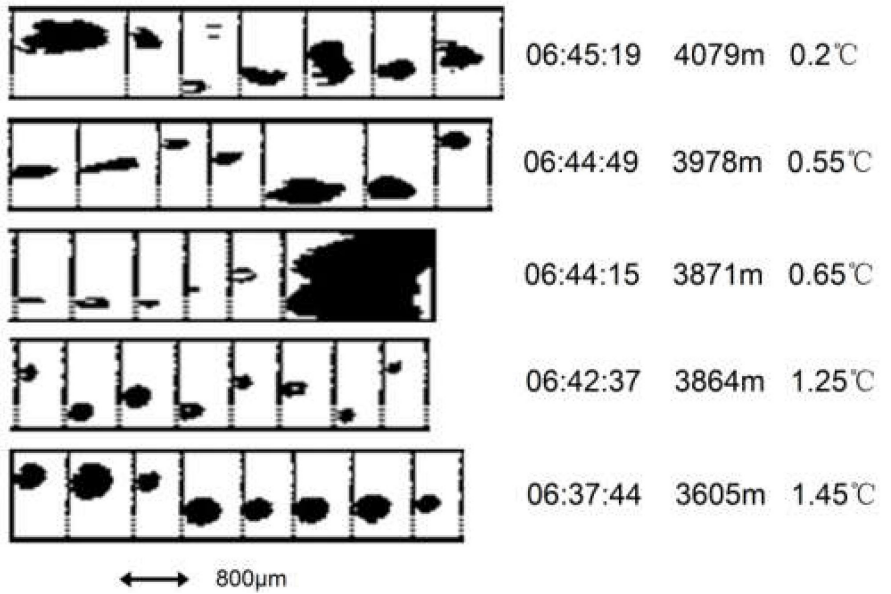

(a)

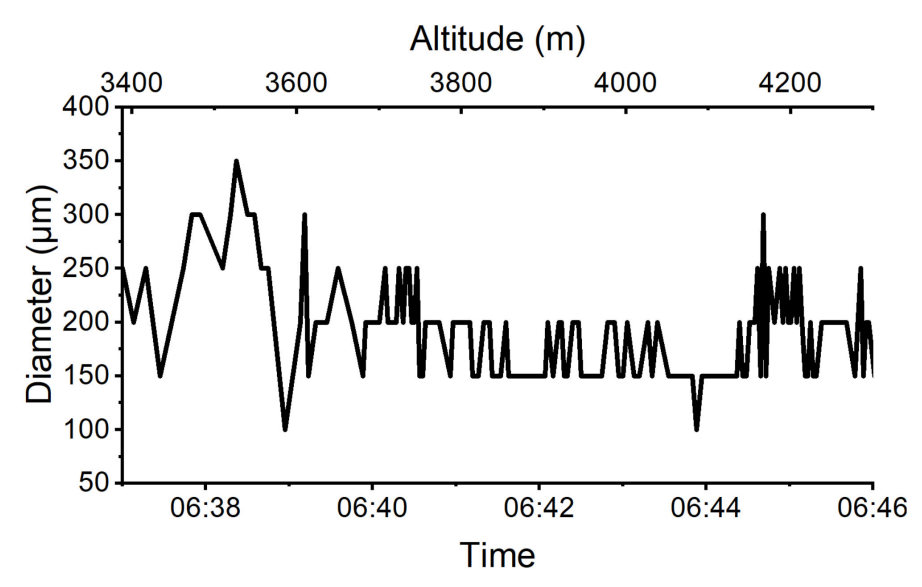

(b)

Figure 8. Measurements of the $2 \mathrm{D}-\mathrm{C}$ probe of (a) particle images and (b) average diameter in the melting layer.

Figure 9a shows the particle images recorded by the PMS-2D-C probe at each level. There were spherical, needle, and irregular ice and snow crystals at altitudes of $4850 \mathrm{~m}$ and $5450 \mathrm{~m}$. The aggregation of ice and snow crystal particles promoted particle growth. Needle ice crystal particles, melting ice crystal particles, and small raindrops occurred at an altitude of $4350 \mathrm{~m}$. Distinguishable needles at $4850 \mathrm{~m}$ and $4350 \mathrm{~m}$ suggest deposition as one of the basic growth mechanisms, and spheres suggest freezing of supercooled droplets.

At an altitude of $5000 \mathrm{~m}$, mainly needle ice and snow crystal particles were observed, while melting ice crystal particles, small raindrop particles, and coalesced particles were observed at an altitude of $4460 \mathrm{~m}$ (as shown in Figure 9b). Aggregation of dendrites could be observed at levels above $4460 \mathrm{~m}$, but was not the dominant process. Only a few $(<10 \%)$ ice particles were pristine in the -3 to $-10^{\circ} \mathrm{C}$ temperature range in the $2 \mathrm{D}$ imageries. A large number of unidentifiable ice particles could have originated from the shattering of larger drops during freezing in fall $[9,14]$.

By collecting the PMS data of many stratiform clouds, Korolev et al. [38] classified ice particles into four categories: spheres, irregulars, dendrites, and needles/columns. Needles absolutely dominated at temperatures from -4 to $-3^{\circ} \mathrm{C}$, in agreement with the results of Korolev et al. [38]. Ice particle habits were characterized by dendrites at $-1{ }^{\circ} \mathrm{C}$, by needles at $-3{ }^{\circ} \mathrm{C}$, and again by dendrites and irregulars at -6 to $-9{ }^{\circ} \mathrm{C}[26,39]$. In comparison, 
needles absolutely dominated at temperatures from -4 to $-3{ }^{\circ} \mathrm{C}$ in this case, which is in agreement with the results of Korolev et al. [38].

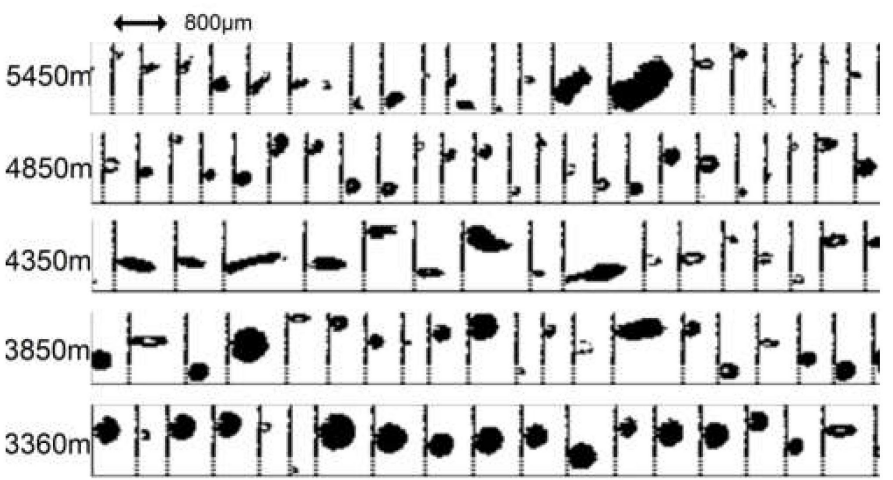

(a)

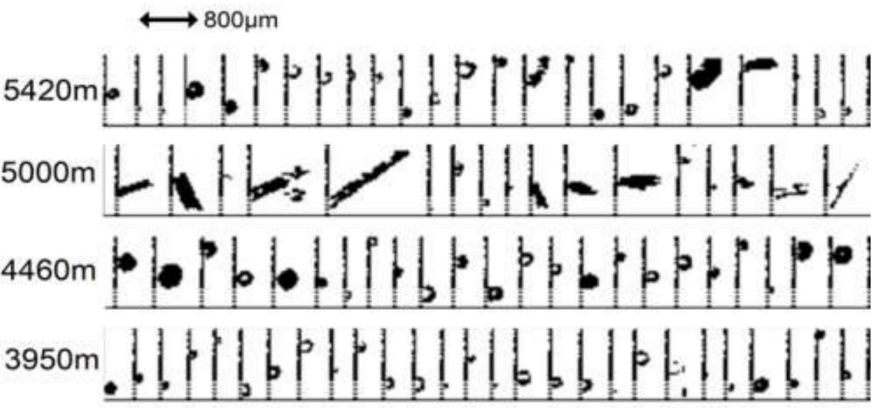

(b)

Figure 9. 2D-C images at selected heights during (a) the first Baicheng Y-12 aircraft flight and (b) the second Baicheng Y-12 aircraft flight.

The typical size spectra of ice particles could not be well sampled by 2D-C alone, and 2D-P was often more sensitive to the presence of large particles than 2D-C [14]. Therefore, we needed to combine the data of $2 \mathrm{D}-\mathrm{P}$ with different sizing ranges to ensure the accuracy of size spectra provided by $2 \mathrm{D}$ probes. Needles occurred at the temperature of $-5.2{ }^{\circ} \mathrm{C}$, the same as the 2D-C (as shown in Figure 10a). Plate-shaped and dendritic ice crystals were observed at altitudes of $4350 \mathrm{~m}$ and $4850 \mathrm{~m}$, and there was an aggregation of snow and ice crystals with the 2D-P. The identification of riming and aggregation levels of ice crystals may roughly depend on their size and density. Aggregation was favorable for the increase in average diameters such as the maximum diameter of $6400 \mu \mathrm{m}$ at $4850 \mathrm{~m}$ for the mixed-phase layer.

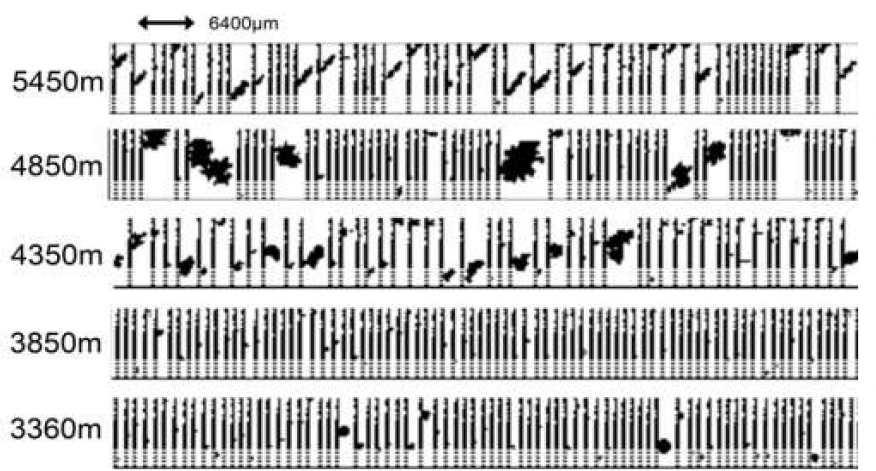

(a)

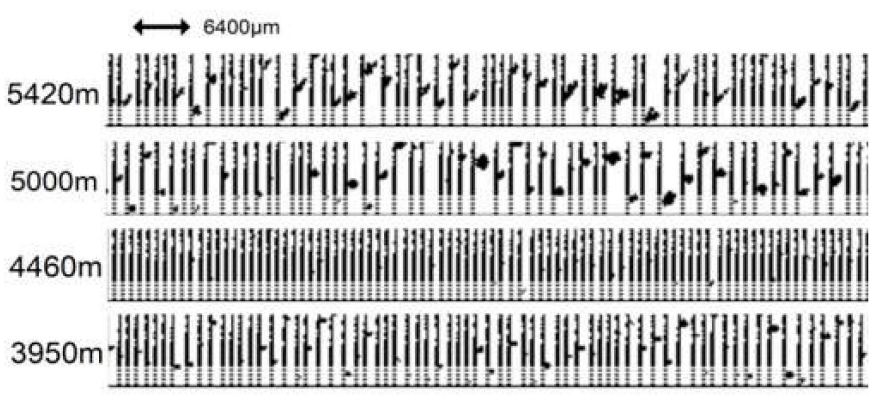

(b)

Figure 10. 2D-P images at selected heights during (a) the first Baicheng Y-12 aircraft flight and (b) the second Baicheng Y-12 aircraft flight.

The needle ice crystals detected had become plate-shaped and dendritic ice crystals were found at altitudes ranging from 5000 to $5420 \mathrm{~m}$ (as shown in Figure 10b). Large precipitation particles such as snow clusters and ice crystal aggregates fell at this altitude, randomly collided with cloud droplets, and fractured, thus causing discontinuities in the large particles at heights from 3950 to $4460 \mathrm{~m}$ and disrupting the particle spectrum (Figure $6 \mathrm{~b}$ ). Ice particle habits in the 2D-P probe were characterized by irregulars and dendrites at 0 to $-2{ }^{\circ} \mathrm{C}$, needles at $-5{ }^{\circ} \mathrm{C}$, and dendrites and irregulars again at $-6{ }^{\circ} \mathrm{C}$.

The majority of ice particles in natural clouds were of irregular shape, found for each $5{ }^{\circ} \mathrm{C}$ temperature interval in the range $-45^{\circ} \mathrm{C}<\mathrm{T}<0{ }^{\circ} \mathrm{C}[38]$. Previous studies [40,41] have discussed the occurrence of columns and needles since they were thought to be associated 
with secondary ice production. Heymsfield and Willis [40] reported that needles were observed primarily in regions of low $\operatorname{LWC}\left(<0.1 \mathrm{~g} \mathrm{~m}^{-3}\right)$ and weak vertical motions $(-1$ to $\left.1 \mathrm{~m} \mathrm{~s}^{-1}\right)$. The combined presence of large droplets exceeding $24 \mu \mathrm{m}$ in diameter and the evident increase in needles occurred most frequently at temperatures of $-5{ }^{\circ} \mathrm{C}$ [13]. In our observations, however, although irregulars were observed, needles and spheres dominated in the observed cloud region of low $\operatorname{LWC}\left(<0.1 \mathrm{~g} \mathrm{~m}^{-3}\right)$ at temperatures from -6 to $-3{ }^{\circ} \mathrm{C}$. Hallet-Mossop criteria were cloud droplet diameter $>25 \mu \mathrm{m},-8{ }^{\circ} \mathrm{C}<\mathrm{T}<-3{ }^{\circ} \mathrm{C}$, and presence of riming (implies that supercooled water and some ice are present) [42]. These cloud conditions fit into the Hallett-Mossop criteria.

\section{Conclusions and Discussions}

In the shallow stratiform cloud area, the growth of particles was mainly condensation, while in the embedded convective and deep stratiform cloud area, the growth of particles included condensation, riming, and aggregation. The aggregation of ice crystals had a greater impact on the broadening of PSDs [15]. However, the aggregation process became very weak in the ML. Due to deep stratiform cloud system dissipation in this study, in which ice and snow crystal particles collided, melted, and precipitated, the concentration of small particles in each layer at the various altitudes was much higher, and the number of large particles decreased. During the dissipation stage, even in deep stratiform clouds, the PSDs in the ML became narrower.

Previous studies suggest that the characteristics of ice crystal habits were different in clouds, and deep clouds with high cloud top and low temperature can produce more complex ice crystal habits such as bullets, dendrites, and aggregates [29,43]. Hou et al. [12] found that needles at $-3{ }^{\circ} \mathrm{C}$ and dendrites and irregulars dominated between -6 and $-9{ }^{\circ} \mathrm{C}$, with few occurrences of spheres. In the embedded convective region, the rimed ice particles and needles dominated at temperatures between -3 and $-5^{\circ} \mathrm{C}$ [13]. However, although irregulars were observed, spheres and needles absolutely dominated from -6 to $-3{ }^{\circ} \mathrm{C}$ in this case.

The ice-bulb temperature is of great importance to the melting process, which controls whether the ice particles are sublimating, growing, or melting [44]. Ice multiplication can occur without the riming process being involved at temperatures of approximately $-5{ }^{\circ} \mathrm{C}$ [45]. The Hallett-Mossop ice multiplication process operated most effectively at the temperature of $-5^{\circ} \mathrm{C}$ in this study. Even at the cloud dissipation stage, the cloud conditions fit into the Hallett-Mossop criteria [42]. Needles and large spheres were observed in the stratiform cloud region of low LWC at temperatures of $-5^{\circ} \mathrm{C}$. High concentrations of cloud droplets and large ice particles provided a favorable environment for ice multiplication in this case.

Previous studies $[10,46]$ have shown that ice crystal concentrations were considerably higher than would have been predicted from the ice nuclei concentrations. Both the highest snow and ice crystal concentrations were approximately $102 \mathrm{~L}^{-1}$. In this study, due to ice multiplication, the highest ice particle concentration reached approximately $287 \mathrm{~L}^{-1}$. Aggregates occurred on more than $50 \%$ of the occasions if the ice particle concentrations were in excess of $103 \mathrm{~L}^{-1}$ and the temperatures above $-5^{\circ} \mathrm{C}$ [47]. Aggregation was present in the dendritic growth region, but was not dominant in this study.

Considering that this study was based on a single case only, in which some errors existed in the instruments, it is necessary to reach general conclusions by examining more cases in future work. Generally, DMT instruments are considered to be more accurate than that of PMS, but it seems the opposite was true in this case. The instrument will be further calibrated at a later date. Nevertheless, the promising results in the current study demonstrate the microphysical characteristics of stratiform clouds in the dissipation stage.

Our observations were obtained at the dissipation stage of cloud precipitation, and further study should focus on the importance of aggregation in the ML. In general, aircraft observations are significant in facilitating research on the properties of stratiform cloud precipitation processes, but they are limited in the analysis of the detailed evolution of 
ML particles [32,33]. Therefore, we plan to use these observations in numerical models for further study of the detailed characteristics of stratiform cloud precipitation.

Author Contributions: H.L. conceived the study, L.W., Y.L. and T.H. contributed to the observation data processing; L.W., W.H., R.Z., M.H., X.Z. and T.H. analyzed the results. All authors have read and agreed to the published version of the manuscript.

Funding: This research was funded by the National Key Research and Development Program of China, grant number 2018YFC1507900, and the National Natural Science Foundation of China, grant number 41705119,41775166 and 41575131.

Institutional Review Board Statement: Not applicable.

Informed Consent Statement: Not applicable.

Data Availability Statement: Data available upon request from all the authors.

Conflicts of Interest: The authors declare no conflict of interest.

\section{References}

1. Houze, R.A. Cloud Dynamics; Academic Press, Inc.: New York, NY, USA, 1993; p. 573.

2. Szoke, E.J.; Zipser, E.J.; Jorgensen, D.P. A Radar Study of Convective Cells in Mesoscale Systems in GATE. Part I: Vertical Profile Statistics and Comparison with Hurricanes. J. Atmos. Sci. 1986, 43, 182-198. [CrossRef]

3. Hobbs, P.V. Research on clouds and precipitation Past, present, and future. Bull. Am. Meteorol. Soc. 1989, 70, 282-285. [CrossRef]

4. Zipser, E.J.; Lutz, K.R. The vertical profile of radar reflectivity of convective cells: A strong indicator of storm intensity and lightning probability. Mon. Weather Rev. 1994, 122, 1751-1759. [CrossRef]

5. Hogan, R.J.; Behera, M.; O'Connor, E.J.; Illingworth, A.J. Estimate of the global distribution of stratiform supercooled liquid water clouds using the LITE lidar. Geophys. Res. Lett. 2004, 31, L05106. [CrossRef]

6. Zhang, D.; Wang, Z.; Kollias, P.; Vogelmann, A.M.; Yang, K.; Luo, T. Ice particle production in mid-level stratiform mixed-phase clouds observed with collocated A-Train measurements. Atmos. Chem. Phys. 2018, 18, 4317-4327. [CrossRef]

7. Hou, T.; Lei, H.; Hu, Z.; Yang, J.; Li, X. Simulations of Microphysics and Precipitation in a Stratiform Cloud Case over Northern China: Comparison of Two Microphysics Schemes. Adv. Atmos. Sci. 2019, 37, 117-129. [CrossRef]

8. Rutledge, S.A.; Hobbs, P. The Mesoscale and Microscale Structure and Organization of Clouds and Precipitation in Midlatitude Cyclones. VIII: A Model for the "Seeder-Feeder" Process in Warm-Frontal Rainbands. J. Atmos. Sci. 1983, 40, 1185-1206. [CrossRef]

9. Rangno, A.L.; Hobbs, P.V. Ice particles in stratiform clouds in the Arctic and possible mechanisms for the production of high ice concentrations. J. Geophys. Res. Earth Surf. 2001, 106, 15065-15075. [CrossRef]

10. Heymsfield, A.J. Precipitation Development in Stratiform Ice Clouds: A Microphysical and Dynamical Study. J. Atmos. Sci. 1977, 34, 367-381. [CrossRef]

11. Orville, H.D.; Farley, R.D.; Hirsch, J.H. Some Surprising Results from Simulated Seeding of Stratiform-Type Clouds. J. Clim. Appl. Meteorol. 1984, 23, 1585-1600. [CrossRef]

12. Hou, T.; Lei, H.; Hu, Z. A comparative study of the microstructure and precipitation mechanisms for two stratiform clouds in China. Atmos. Res. 2010, 96, 447-460. [CrossRef]

13. Hou, T.; Lei, H.; He, Y.; Yang, J.; Zhao, Z.; Hu, Z. Aircraft Measurements of the Microphysical Properties of Stratiform Clouds with Embedded Convection. Adv. Atmos. Sci. 2021, 38, 966-982. [CrossRef]

14. Yang, J.; Lei, H.; Hu, Z.; Hou, T. Particle size spectra and possible mechanisms of high ice concentration in nimbostratus over Hebei Province, China. Atmos. Res. 2014, 142, 79-90. [CrossRef]

15. Zhu, S.C.; Guo, X.L.; Lu, G.X.; Guo, L. Ice crystal habits and growth processes in stratiform clouds with embedded convection examined through aircraft observation in northern China. J. Atmos. Sci. 2015, 72, 2011-2032. [CrossRef]

16. Heymsfield, A.J.; Bansemer, A.; Poellot, M.R.; Wood, N. Observations of Ice Microphysics through the Melting Layer. J. Atmos. Sci. 2015, 72, 2902-2928. [CrossRef]

17. Mason, S.L.; Chiu, C.J.; Hogan, R.J.; Moisseev, D.; Kneifel, S. Retrievals of Riming and Snow Density From Vertically Pointing Doppler Radars. J. Geophys. Res. Atmos. 2018, 123, 13-807. [CrossRef]

18. Tridon, F.; Battaglia, A.; Chase, R.J.; Turk, F.J.; Leinonen, J.; Kneifel, S.; Mroz, K.; Finlon, J.; Bansemer, A.; Tanelli, S.; et al. The Microphysics of Stratiform Precipitation During OLYMPEX: Compatibility Between Triple-Frequency Radar and Airborne In Situ Observations. J. Geophys. Res. Atmos. 2019, 124, 8764-8792. [CrossRef]

19. Heymsfield, A.J.; Schmitt, C.; Bansemer, A. Ice Cloud Particle Size Distributions and Pressure-Dependent Terminal Velocities from In Situ Observations at Temperatures from $0^{\circ}$ to $-86^{\circ}$ C. J. Atmos. Sci. 2013, 70, 4123-4154. [CrossRef]

20. Willis, P.T.; Heymsfield, A.J. Structure of the melting layer in mesoscale convective storm stratiform precipitation. J. Atmos. Sci. 1989, 46, 2008-2025. [CrossRef] 
21. Carlin, J.T.; Ryzhkov, A.V. Estimation of Melting-Layer Cooling Rate from Dual-Polarization Radar: Spectral Bin Model Simulations. J. Appl. Meteorol. Clim. 2019, 58, 1485-1508. [CrossRef]

22. Szeto, K.K.; Lin, C.A.; Stewart, R.E. Mesoscale Circulations Forced by Melting Snow. Part I: Basic Simulations and Dynamics. J. Atmos. Sci. 1988, 45, 1629-1641. [CrossRef]

23. Trömel, S.; Ryzhkov, A.V.; Hickman, B.; Mühlbauer, K.; Simmer, C. Polarimetric Radar Variables in the Layers of Melting and Dendritic Growth at X Band-Implications for a Nowcasting Strategy in Stratiform Rain. J. Appl. Meteorol. Clim. 2019, 58, 2497-2522. [CrossRef]

24. Oraltay, R.G.; Hallett, J. The Melting Layer: A Laboratory Investigation of Ice Particle Melt and Evaporation near $0{ }^{\circ} \mathrm{C} . \mathrm{J}$. Appl. Meteorol. 2005, 44, 206-220. [CrossRef]

25. Heymsfield, A.J.; Bansemer, A.; Theis, A.; Schmitt, C. Survival of Snow in the Melting Layer: Relative Humidity Influence. J. Atmos. Sci. 2021, 78, 1823-1845. [CrossRef]

26. Zawadzki, I.; Szyrmer, W.; Bell, C.; Fabry, F. Modeling of the Melting Layer. Part III: The Density Effect. J. Atmos. Sci. 2005, 62, 3705-3723. [CrossRef]

27. Li, H.; Von Lerber Tiira, A.J.; Moisseev, D. Towards the connection between snow microphysics and melting layer: Insights from multi-frequency and dual-polarization radar observations during BAECC. Atmos. Chem. Phys. Disc. 2020, 20, 9547-9562. [CrossRef]

28. Pruppacher, H.; Klett, J. Microphysics of Clouds and Precipitation; Atmospheric and Oceanographic Sciences Library 18; Kluwer Academic Publishers: Dordrecht, The Netherlands, 1997.

29. Evans, A.G.; Locatelli, J.D.; Stoelinga, M.T.; Hobbs, P.V. The IMPROVE-1 Storm of 1-2 February 2001. Part II: Cloud Structures and the Growth of Precipitation. J. Atmos. Sci. 2005, 62, 3456-3473. [CrossRef]

30. Woods, C.P.; Stoelinga, M.T.; Locatelli, J.D. Size Spectra of Snow Particles Measured in Wintertime Precipitation in the Pacific Northwest. J. Atmos. Sci. 2008, 65, 189-205. [CrossRef]

31. Yang, J.; Wang, Z.; Heymsfield, A.J.; DeMott, P.J.; Twohy, C.H.; Suski, K.J.; Toohey, D.W. High ice concentration observed in tropical maritime stratiform mixed-phase clouds with top temperatures warmer than $-8{ }^{\circ} \mathrm{C}$. Atmos. Res. 2019, 233, 104719. [CrossRef]

32. Field, P.R. Aircraft Observations of Ice Crystal Evolution in an Altostratus Cloud. J. Atmos. Sci. 1999, 56, 1925-1941. [CrossRef]

33. Heymsfield, A.J.; Bansemer, A.; Field, P.; Durden, S.L.; Stith, J.L.; Dye, J.E.; Hall, W.; Grainger, C.A. Observations and Parameterizations of Particle Size Distributions in Deep Tropical Cirrus and Stratiform Precipitating Clouds: Results from In Situ Observations in TRMM Field Campaigns. J. Atmos. Sci. 2002, 59, 3457-3491. [CrossRef]

34. Nakaya, U. Snow Crystals: Natural and Artificial; Harvard University Press: Cambridge, MA, USA, 1954.

35. You, L.G.; Xiong, G.Y.; Gao, M.R.; Lu, Y.J.; Sun, K.F.; Ren, D.F. The characteristics of ice crystal formation and snow growth processes of in spring stratiform clouds in Jilin Province. Acta Meteorol. Sin. 1965, 35, 423-433. (In Chinese)

36. Hobbs, P.V.; Rangno, A.L. Ice Particle Concentrations in Clouds. J. Atmos. Sci. 1985, 42, 2523-2549. [CrossRef]

37. Crawford, I.; Bower, K.N.; Choularton, T.W.; Dearden, C.; Crosier, J.; Westbrook, C.; Capes, G.; Coe, H.; Connolly, P.J.; Dorsey, J.R.; et al. Ice formation and development in aged, wintertime cumulus over the UK: Observations and modelling. Atmos. Chem. Phys. 2012, 12, 4963-4985. [CrossRef]

38. Korolev, A.; Isaac, G.A.; Hallett, J. Ice particle habits in stratiform clouds. Q. J. R. Meteorol. Soc. 2000, 126, 2873-2902. [CrossRef]

39. Pruppacher, H.R.; Klett, J.D. Microphysics of Clouds and Precipitation; Reidel: Boston, MA, USA, 1978; pp. 44-47.

40. Heymsfield, A.; Willis, P. Cloud Conditions Favoring Secondary Ice Particle Production in Tropical Maritime Convection. J. Atmos. Sci. 2014, 71, 4500-4526. [CrossRef]

41. Field, P.R.; Lawson, R.P.; Brown, P.R.A.; Lloyd, G.; Westbrook, C.; Moisseev, D.; Miltenberger, A.; Nenes, A.; Blyth, A.; Choularton, T.; et al. Chapter 7. Secondary Ice Production-Current state of the science and recommendations for the future. Meteorol. Monogr. 2016, 58, 7.1-7.20. [CrossRef]

42. Hallett, J.; Mossop, S.C. Production of secondary ice particles during the riming process. Nature 1974, 249, 26-28. [CrossRef]

43. Stark, D.; Colle, B.A.; Yuter, S.E. Observed Microphysical Evolution for Two East Coast Winter Storms and the Associated Snow Bands. Mon. Weather Rev. 2013, 141, 2037-2057. [CrossRef]

44. Kneifel, S.; von Lerber, A.; Tiira, J.; Moisseev, D.; Kollias, P.; Leinonen, J. Observed relations between snowfall microphysics and triple-frequency radar measurements. J. Geophys. Res. Atmos. 2015, 120, 6034-6055. [CrossRef]

45. Knight, C.A. Ice growth from the vapor at $-5^{\circ}$ C. J. Atmos. Sci. 2012, 69, 2031-2040. [CrossRef]

46. Hobbs, P.V.; Houze, R.A.; Matejka, T.J. The Dynamical and Microphysical Structure of an Occluded Frontal System and its Modification by Orography. J. Atmos. Sci. 1975, 32, 1542-1562. [CrossRef]

47. Hobbs, P.V.; Chang, S.; Locatelli, J.D. The dimensions and aggregation of ice crystals in natural clouds. J. Geophys. Res. Earth Surf. 1974, 79, 2199-2206. [CrossRef] 